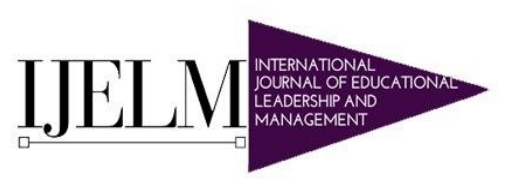

Hipatia Press

Instructions for authors, subscriptions and further details:

http://ijelm.hipatiapress.com

\title{
Organizational and environmental contexts affecting school principals' distributed leadership practices.
}

\section{Neşe Börü ${ }^{1}$}

1) Nevşehir Hacı Bektaş Veli Üniversitesi, Turkey.

Date of publication: July $16^{\text {th }}, 2020$

Edition period: July 2019 - July 2020

To cite this article: Börü, N. (2020). Organizational and environmental contexts affecting school principals' distributed leadership practices. International Journal of Educational Leadership and Management. doi: 10.17583/ijelm.2020.4482

To link this article: http://dx.doi.org/10.17583/ijelm.2020.4482

\section{PLEASE SCROLL DOWN FOR ARTICLE}

The terms and conditions of use are related to the Open Journal System and to Creative Commons Attribution License (CCAL). 


\section{Organizational and environmental contexts affecting school principals' distributed leadership practices.}

Neşe Börü

Nevşehir Hacı Bektaş Veli Üniversites

Turkey

\section{Abstract}

The aim of this study is to determine the organizational and environmental contexts that affect the distributed leadership behaviours of school principals working in primary schools in Turkey. A phenomenological research approach has been adopted and data was collected via semi-structured interviews conducted with 15 primary school principals. Maximum variation sampling strategy is used in recruiting participants and the collected data was analysed using content analysis. The results suggested that legislations, school culture, parents' and students' culture, national culture, and centralized and bureaucratic structure affect the attitude school principals distribute the leadership in schools. School principals generally do not want to share leadership with teachers or parents. While the justification about teachers is based on their reluctance to take responsibility or the negative competition between them, the justification for parents is based on the potential of parents' leadership to be a threat towards social justice at school. In addition, the law puts more responsibility on school principals, pushing them to become the leader of the school. However, school principals do not have as much authority as responsibility at schools. Thus, the hierarchical structure that intensifies the power in the center will provide more effective control over the school.

Keywords: School principals, distributed leadership, organizational barriers, environmental barriers. 


\section{Contextos organizacionales y ambientales que afectan las habilidades de liderazgo distribuido de los directores escolares.}

Neşe Börü

Nevşehir Hacı Bektaş Veli Üniversitesi

Turkey

\section{Resumen}

El objetivo de este estudio es determinar los contextos organizacionales y ambientales que afectan a la distribución del liderazgo de los directores de escuelas de Educación primaria en Turquía. La investigación tiene un enfoque fenomenológico, los datos se recopilaron a través de entrevistas semiestructuradas realizadas a 15 directores de escuelas de Educación Primaria. La estrategia de muestreo de variación máxima se utiliza para reclutar participantes. Los datos se analizaron mediante un análisis de contenido. Los resultados sugirieren que las legislaciones, la cultura escolar, la cultura de las familias y de los estudiantes, la cultura nacional, la estructura centralizada y la burocracia afectan a la actitud de los directores escolares a la hora de distribuir el liderazgo. Los directores generalmente no quieren compartir el liderazgo con los maestros o familias. Si bien la justificación en relación a los maestros se basa en su renuncia a asumir la responsabilidad o la competencia negativa entre ellos. La justificación para las familias se basa en el potencial del liderazgo de familias es una amenaza hacia la justicia social en la escuela. Además, la ley pone más responsabilidad en los directores empujándolos a convertirse en el líder de la escuela. Sin embargo, los directores de escuela no tienen tanta autoridad ni responsabilidad en las escuelas. Por lo tanto, la estructura jerárquica que intensifica el poder en el centro proporcionará un control más efectivo sobre la escuela.

Palabras clave: Directores escolares, liderazgo distribuido, barreras organizacionales, barreras ambientales. 
7 he The professional development of teachers has been found to be an important factor for the success of schools and the students (Canales \& Maldonado, 2018; Darling-Hammond, 2000; Garet, Porter, Desimone, Birman, \& Yoon, 2001; Goldhaber \& Anthony, 2003; Lumpe, Czerniak, Haney \& Beltyukova, 2012; Stronge, Ward, Tucker \& Hindman, 2007; Yoon, Duncan, Lee, Scarloss \& Shapley, 2007). The performance of teachers depends on their motivations, capacities and working conditions. In addition, there is a visible effect that school principals have on teachers' working conditions. School principals strive for the development of goals which inspire teachers and on which there is a school-wide consensus. Effective school principals value teachers' ideas, are considerate, and support teachers when necessary. Effective school principals work to increase the welfare in schools and improve teachers professionally by distributing leadership, keeping the promises they make, rewarding teachers when necessary, and providing feedback to teachers about their teaching practices. Such services, provided by school principals, enhance teachers' motivation and their organizational commitment levels (Hoy \& Tarter, 1992; Leithwood, 2006; Tschannen-Moran, Hoy \& Hoy, 1998). Therefore, school principals' impact on student achievement is indirect (Bossert, Dwyer, Rowan \& Lee, 1982; Hallinger \& Heck, 1998, 1996; Robinson, 2007; Witziers, Bosker \& Krüger, 2003). Their impact on student achievement is based on the decisions they make about teaching and learning and the importance they place on the development of school-related processes (Bossert et al., 1982; Dinham, 2005; Heck \& Hallinger, 2009; Hallinger, 2011; Leithwood, Patten \& Jantzi, 2010). In school development, both school principals and teachers have important but different roles. In particular, leadership remains an important success factor in improving a school in contexts with the greatest challenges (Hallinger \&_Heck, 2009). For this reason, it is necessary to pay attention to the behaviour of the school principals who have the leadership positions in schools.

The behaviour of school principals, according to system theory, is shaped by the organizational and environmental contexts. The effectiveness of school principals depends on overcoming school problems and seizing opportunities within both organizational and environmental contexts (Allen, 
Stelzner \& Wielkiewicz, 1999; Hallinger, 2018, 2011; Harris, 2004). Researchers suggest that school principals should share their duties with school members rather than shouldering those duties, like a hero, on their own (Spillane, 2005; Yukl, 1999). Similarly, studies have shown that distributed leadership has positive effects on student achievement, school development and change (Copland, 2003; Firestone \& Cecilia Martinez, 2007; Hallinger \& Heck, 2010a, 2010b; Heck \& Hallinger, 2010a, 2010b, 2009; Harris, Leithwood, Day, Sammons \& Hopkins, 2007; Harris, 2004; Humphreys, 2010; Tan, 2018). Furthermore, distribution of leadership by school administrators plays an important role in building trust, cooperation and respect among employees (Bellibas \& Liu, 2018). Such collaborations also improve the professional capacities of employees (Pearce, Manz \& Sims Jr, 2009; Pearce \& SimsJr, 2002). Distributed leadership also has a significant positive effect and a key role in teachers' commitment to school decisions (Angelle, 2010; Hallinger \& Lu, 2014; Hartley, 2010; Hulpia, Devos, Rosseel \& Vlerick, 2012; Hulpia, Devos \& Van Keer, 2010; Mascall, Leithwood, Straus \& Sacks, 2008).

The concept of distributed leadership can be traced back to 1950s in the field of social psychology (Gronn, 2002). The terms "distributed leadership", "shared leadership", "team leadership" and "democratic leadership" can be used interchangeably. While distributed leadership is defined by some as a way of thinking about the practices of the school principal, others define it as having more than one leader in the school, or attributing leadership to the organization rather than handing it over to an individual. Distributed leadership is about leadership practices rather than leaders' roles or characteristics. From a distributed perspective, leadership practices are products of the interaction of people and situations rather than being the products of leaders' knowledge and skills. Often, distributed leadership is addressed as having more than one leader in a school. However, this is only one of the visible facets of distributed leadership. Distributed leadership refer to leadership practices that are formed as a result of the interactions among leaders, followers, and situations (Spillane, 2005). In organizations, there could be leaders with same roles who can make successful decisions by controlling each other's decisions and performances. On the other hand, it is also possible for leaders to complement each other, learn from each other, 
and have different roles, which can create a positive atmosphere of competition (Gronn, 2002). The distribution of leadership among teachers can lead to competition and result in some teachers being more in the forefront in comparison to other teachers, which can potentially cause problems. In order to overcome such difficulties, there is a need to create teams that bring together the strengths of teachers in a school, and a school culture that allows change and supports the leadership of teachers (Harris, 2004).

There is a need for in-depth analyses of how leadership is distributed in schools or the logic behind it since much of the work on leadership work focuses on leadership practices. The analyses that have been made so far remain inadequate in terms of how and why leaders are undertaking such practices (Spillane, 2005; Spillane, Halverson \& Diamond, 2001). Findings on the models and effects of distributed leadership on organizational development and change are quite extensive. However, more information is required to understand the size and nature of this effect. In addition, there is also a need for further research on understanding the potential of distributed leadership, any unexpected results of distributed leadership, and its limitations and dangers as well as barriers (Harris et al., 2007).

The behaviour of school principals, who have responsibilities in terms of the organizational and environmental contexts, is under the influence of their personal values and experience, the institutional system, policies, economy, social culture, the character of the school community and student outcomes (Hallinger, 2018; 2011). Research in leadership and school development often emphasizes the advantages of distributed leadership. On the other hand, there are studies that state structural, cultural and micro-political barriers affect the applicability of distributed leadership in schools (Harris, 2004). The region is one of the most crucial factors that influence how leadership is managed in schools. Considering this, research on how regional contexts affect distributed leadership practices in schools will enrich the relevant literature (Park \& Datnow, 2009). The examination of existing literature on the factors affecting the distribution of leadership among school principals, teachers and parents suggest that there is a lack of research in this 
area. In addition, from a cultural perspective, the present study aims to contribute to literature by analysing the case of Turkey. The present study has been structured following Hallinger's (2018) classification of factors affecting distributed leadership. The purpose of this study is to determine how institutional, social, national, economic and political contexts affect the behaviour of primary school principals' behaviour related to the distribution of leadership in schools.

\section{Contexts affecting leadership in schools}

Hallinger (2018) identified the factors that influence leadership behaviour as shadows of leadership and classified them as institutional, societal, national, economic, political, and school development contexts. This study did not consider the school development context that was part of Hallinger's (2018) framework since it had not been evaluated with empirical evidence in Turkey.

\section{Institutional context}

School principals' work contexts are shaped by interplay of different factors such as school district's aims, structures, initiatives, size and norms (Hallinger, 2018). Traditional hierarchical structures in schools may not immediately adapt to the distribution of leadership. Moreover, existing status quo can consider the sharing of leadership as a threat because distributed leadership requires individuals in official leadership positions to transfer power to others. Loss or delegation of authority, apart from ego problems, renders school principals vulnerable. This is because school principals' direct control over a number of practices in schools weakens. The hierarchical structure of schools is designed in such a way that the power is in the hands of the leadership team in both the primary and secondary schools. Academic separation (e.g. English, math, history, science) of teachers makes it difficult to distribute leadership among teachers. This is because the subject areas they teach give teachers autonomy and may prevent them from actively assuming leadership roles in schools (Harris, 2004). According to the conceptual framework established by Thompson (1967) to explain the dependencies between the members of an organization, 
the behaviour of the teachers is explained as a docked structure (individuals working independently use common resources). While teachers share the facilities and income sources of the school together, they work alone with their students (Mintzberg, 1979).

Institutional structure also affects the workload within schools. In betterstructured education systems, school principals have shorter working hours due to managerial workloads. In addition, better-formalized official documents reduce the uncertainty in school principals' managerial duties. Centralization of the system is another factor that shapes the working areas of school principals. While the education system is over centralized in countries such as Russia, South Korea, China, Thailand, Turkey, Greece, and Vietnam; a decentralized structure exists in countries such as the USA, Australia, Canada, New Zealand, England, and Hong Kong. While most American, Canadian, and English school principals have the authority to hire teachers; school principals in many other countries such as Thailand and Vietnam do not possess such authority. In such countries, teachers are recruited by the Ministries of National Education (Hallinger, 2018).

As a result of globalization, the educational reforms developed after 2000s focus on accountability and quality at the system level all over the world and these policies affect the role descriptions and behaviours of school principals. For example, in 1990s, the process of evaluating teachers was a ritual and teachers who would be found to be inadequate in their jobs would rarely be fired from their jobs. Two decades later, reform policies in the United States have made it possible to fire ineffective teachers and school principals. Similar practices can be observed in countries like England, Belgium, Italy, Hong Kong, and South Korea (Hallinger, 2018).

\section{Societal context}

The behaviour of school principals is under the influence of the societal context. The societal context is shaped by topics such as the establishment of goals for school principals' leadership practices, the supervision of teaching, 
and the involvement of parents. For example, school principals of schools with high socio-economic conditions experience more active instructional leadership roles compared to those with lower socio-economic conditions. The consequences of a school being in the city or in the countryside are also considered as the societal context. Especially, the academic achievement of countryside schools in developing countries is lower compared to city schools. The physical and financial insufficiencies of the school and inefficacy of the staff working in rural areas are considered to be the causes of this situation. Not only resource shortages but also safety and lack of success are among the problems that the school principals should overcome. These problems not only affect the school principals' leadership practices, but also raise the bar for showing their leadership practices. Internal conflicts within a society, such as war, may also affect the behaviour of school principals (Hallinger, 2018).

Research shows that distributed leadership can be affected by the relationship among teachers as well as the school management. Teachers can sometimes be against distributed leadership because of factors such as inertia, excessive cautiousness, and insecurity. Furthermore, distributed leadership may lead to conflicts by generating alienation among teachers who assume and do not assume leadership roles (Barth, Haycock, Jackson, Mora, Ruiz, Robinson \& Wilkins, 1999). In order to overcome these difficulties, the teacher leaders' ability to engage in interpersonal relationships should be strong and there should be a school culture that encourages change and leadership (Harris, 2004). In short, seizing schools' opportunities and managing available resources, needs, and limitations affect leaders' abilities (Hallinger, 2018).

\section{National cultural context}

Each culture has its own forms of behaviour. A culture's specific practices and beliefs cannot be understood without becoming a part of that culture (Dimmock \& Walker, 2005). Research on how the national culture affects the leadership dynamics in schools generally utilizes Hofstede's (1980) national culture framework (Hallinger, 2018). According to the results of the 
study conducted by Sargut (2001) in Turkey, which utilized Hofstede's (1980) framework, the Turkish society is described as a low-synergy culture. The Turkish society is divided into sub-groups within itself. Each group recognizes another group as opposition and gives particular importance to their gains while remaining indifferent to others' losses. Personal relationships or interests are taken into account in the selection of leaders. In particular, there is a sense of management which does not take skills and talents into consideration, a management that is far from professionalism, extremely centralist, and which does not provide management opportunities to subordinates. Turkish society is considered among societies with low levels of societal trust.

\section{Economic context}

Despite limited quantitative research, the level of economic development is another important factor that directs school principals' work in terms of; teacher quality, class size, per capita expenditures, parental education and participation, school facilities, the size and quality of libraries, and access to technology. Limitations in the payment scale may not immediately respond to distributed leadership, so distributed leadership may also be affected by financial barriers (Harris, 2004). According to the study conducted by Hallinger (2018), although school administrators in economically developed countries did not spend much time on instructional leadership, that time was still considered to be more than the time that school administrators in developing countries spend on instructional leadership.

\section{Political context}

Policies are structures that direct people about what they can and cannot do; limit or modify the options available to them for making decisions; and pave the way to the formation of specific goals and results. It is considered that policies can be implemented without problems as they come into force. On the contrary, policies are subject to interpretation rather than direct 
application. That is to say, while policies seem to be explicitly applied from the outside, they can be interpreted in a way that responds to the conditions of schools. During the transformation process of policies, necessary observations are made and dialogues are established, and policies are restructured based on the analyses of currently practiced policies. In this process, the support of educational workers is a key feature (Braun et al., 2011). National objectives of education determine what issues will be given the highest priority in education. These are generally defined by political authorities within a society. These goals are forgotten when considering academic achievement on a global basis. Nevertheless, there are international differences in the meanings attached to educational objectives. Therefore, the political context shapes the behaviour of school leaders (Hallinger, 2018).

\section{The aim of the study}

Raising individuals who can take responsibility is important for the welfare of a society. Primary schools that form the basis of education have an important place in raising individuals with leadership qualities. Therefore, the present study considered the investigation of primary school principals (who can be considered as role models for youngsters) and their views on distributing leadership a worthwhile investigation.

The purpose of this study is to determine how institutional, social, national, economic, and political contexts affect the behaviour of primary school principals in terms of distributing leadership.

\section{Research design}

\section{Methods}

Phenomenology, which is a qualitative research design, was adopted in the present study in order to collect detailed and systematic data on the subject of interest. Phenomenological approach aims to understand participants' perceptions and perspectives on a particular issue through deep and 
unstructured negotiations. The sample size in phenomenological studies usually ranges from 5 to 25 (Leedy \& Ormrod, 2001).

\section{Participants}

Maximum variation sampling strategy was followed in recruiting primary school principals. Maximum variation sampling strategy aims to find common patterns among participants with different characteristics or participants recruited based on different criteria (Patton, 2014). The participants of the present study were 15 school principals working in primary schools in which students were classified as having high, medium, or low socio-economic levels. Participants code names, demographics, and schools' socio-economic levels are presented in Table 1.

Table 1. Participant demographics

\begin{tabular}{lllll}
\hline $\begin{array}{l}\text { Code names for } \\
\text { principals }\end{array}$ & $\begin{array}{l}\text { The gender of } \\
\text { principals }\end{array}$ & $\begin{array}{l}\text { Principals' } \\
\text { experience in years }\end{array}$ & $\begin{array}{l}\text { Highest degree } \\
\text { principals achieved }\end{array}$ & $\begin{array}{l}\text { Schools socio- } \\
\text { economic levels }\end{array}$ \\
\hline P1 & Male & 15 & Bachelors & High \\
P2 & Female & 13 & Bachelors & Medium \\
P3 & Female & 5 & Masters & Medium \\
P4 & Male & 30 & Bachelors & Medium \\
P5 & Male & 5 & Bachelors & High \\
P6 & Male & 7 & Bachelors & Medium \\
P7 & Male & 15 & Bachelors & Low \\
P8 & Male & 8 & Bachelors & Low \\
P9 & Male & 10 & Bachelors & Low \\
P10 & Male & 15 & Bachelors & Low \\
P11 & Male & 9 & Bachelors & Low \\
P12 & Male & 10 & Bachelors & Low (Rural area) \\
P13 & Male & 19 & Bachelors & High \\
P14 & Male & 30 & Bachelors & Medium \\
P15 & Male & 20 & Bachelors & Medium \\
\hline
\end{tabular}

\section{Data Collection Tools and Procedure}

A semi-structured interview schedule was used to collect the data of the study. Interview questions were prepared in accordance with the aim of the study. The interview schedule consisted of a total of 12 open-ended 
questions (Appendix) based on Hallinger's (2018) framework and prompts. The questions were reviewed by a panel of experts and a pilot took place with one school administrator. Thus, the internal validity was established. The interview schedule was made available to participants beforehand and their consent was received before the interviews. Attempts were made to develop an interaction with participants that is based on trust and empathy and it was expected that they would respond sincerely to questions asked.

\section{Data analysis}

The collected data was analysed using deductive analysis, which is one of the content analysis techniques. The themes and categories were determined based on Hallinger's (2018) framework (Patton, 2014). In addition, Merriam's (1988) steps for content analysis were followed. Firstly, the collected data were coded into meaningful units. The units can be words, sentences, paragraphs, or pages and each unit is evaluated in terms of what it means and is then coded. In the second stage, the codes generated were brought together in search for themes. In the third stage, the codes and themes generated were organized and explained in a meaningful way that can be understood by readers. In the fourth stage, the codes that were presented in a systematically way were discussed and commented on in search for a conclusion.

\section{Content validity and reliability}

Validation strategies necessary for qualitative research as suggested by Christensen et al. (2015) were followed in establishing the validity of the study. During the selection of participants, the schools were classified as high, medium, and low in terms of the socio-economic levels of their students which increased the diversity achieved in the study and, therefore, supported internal validity. In results section, the views of school principals were discussed in detail and where possible contrasting ideas were presented in order to increase the validity. In addition, during the data collection 
process, prompts and probes were utilized in order to gather rich and detailed data. This was done in order to serve the elaborative researcher approach. Direct quotations were included in order to support the findings. The results obtained at the end of the study and participants checked researchers' comments to establish the interpretation validity. Researchers in the field were consulted in the process of analysing and interpreting the data. The reliability of the analysis was established using the following formula:

"Reliability $=$ Number of Agreements / Number of Agreements + Number of Disagreements)."

Over $70 \%$ of agreement suggests that the data analysis is reliable (Miles \& Huberman, 1994). According to this calculation, the reliability was found as $83 \%$.

\section{Findings}

The responses interviewees provided to questions asked were categorized into 5 themes. These categories were: (1) legislation, (2) school culture, (3) parents' and students' culture (4) national culture, and (5) the centralized and bureaucratic structure.

\section{Legislation}

All participants stated that the current laws indicate school principals have the maximum liability for the duties and responsibilities within schools. One opinion expressed on this matter is included in the following paragraphs.

"In any project, the first person to be accountable is the school principal. Because of that, principals try to get the job done with the least possible risk. But leaders take risks and lead the staff to success. I 
mean, it's not exactly leadership that we [the school principals] are doing right now. In current conditions, $95 \%$ of the school principals are doing school management" (P11).

Participants had the perception that school principals were the most accountable individuals in schools according to legislation, which causes school principals to share leadership in a way that was more controlled and centralized. Other reasons that prevent sharing leadership at school are discussed under the theme of school culture and school principals' views of distributed leadership.

\section{School culture}

In order to be able to accord to legislation and ensure the effectiveness in schools, most of the school principals who participated in this study considered that a school principal had to be the leader of the school and teachers had to be the co-leaders of principals.

P2's, P9's and P8's views on those teachers should be co-leaders in school:

"Not everyone can be a leader in this school. Everyone can specialize in one area and can be a leader in one area. Nevertheless, the last decisions should be made by the one who is the director, if it is for the benefit of the school (P2)."

"We distribute the power and duties among teachers and monitor them. The reason we exist in this school is to guide and help, and when necessary interfere, monitor (P9)."

"A system that everyone is a leader will not work. There is a sound from every head. I do not allow such a thing to be just, the prominent leader can act in his own interests. But we assign duties, we choose the person who will do the job best. When you assign tasks, if you always choose the same people, teachers will be leaders, this will not be true, we should achieve that balance. Institutional culture does not want the same people to be selected, 
teachers are jealous of each other. Teachers like to take tasks. They don't want one of them to be leaders in school. The teachers compete with each other saying, "Let me take a duty!" If we always assign the same person, that person will be arrogant. If I raise one as a success at school, that person will prevail over others. He can also head to the school principal. If the principal loses his leadership, he becomes the administrator by law, but not the leader (P8)."

On the other hand, P4 concluded that giving teachers more authority and responsibility was more correct as a result of the conversation with the researcher.

"In my conversation with you, I saw myself missing. What is the lack I see? I was misinterpreting my leadership understanding. As a result of the impression that I got from you, now, my first job in the new period will be to give them authority and responsibility. I empowered teachers, but he was not responsible. I was responsible. Now I will give responsibility now. As you appreciate, people who take over the entire load are more prone to make mistakes (P4)."

Even though P10 stated that some teachers have leadership qualities and take initiatives, he added that the decisions these teachers make occasionally contradict rules and regulations and that the school principal is the one who would draw the lines for such actions and make the final decision. So, P10 also considered that teachers should be co-leaders in school.

"There are teachers among staff who are really hardworking, who take on responsibilities, and who try hard to improve the conditions of the school. [...] The school principal should draw the boundaries when necessary. [...] That is to say the school principal leads the school within the limits of rules and regulations (P10)."

On the other hand, some teachers do not want to be given duties about school administration. P9's views on teachers' unwillingness not wanting to 
take responsibility indicate that teachers accept the principal as the member of staff with highest responsibility:

"In terms of solving problems, it is the principal who uses authority and establishes a well-functioning climate. Would there be any volunteer to take such responsibility? Teachers say that they have authority in classroom management and are happy with that. Teachers expect such authority from the principal."

There are not many volunteer teachers who want to share the duties and responsibilities of the school. P15's views on teachers who are willing to be assigned roles in school:

"The number of teachers who wants to step forward is usually no more than 10 or $20 \%$. Let's also say that those who do not want to volunteer are about $20 \%$ (these teachers are generally close to retirement). Those who are in the middle are about $60 \%$. Those are the ones who would do what you want them to do."

Sometimes giving autonomy to teachers can cause some problems at school. For example, P1 considered that some primary school teachers do not see their classes as part of the school. This point of view damages other teachers' ability to affect all students in the school. Especially teachers on duty, who are responsible to monitor students during breaks, can experience problems in managing students' behaviours; for example, students do not listen to this teacher's instructions. P1 indicated that this situation is not the case in the all schools that he works in and added that having teachers act this way results from teachers wanting to be the best teacher in a school or the informal competition atmosphere in that school. According to P1, teachers desire to be popular; in fact, they are in search of inner satisfaction. P1's view:

"There are teachers who put the dust they collected from the class into the hallway, that is to say they embrace only their class. There are teachers in our school who tell the students that they are different than other than 
students in other classes, no one can interfere with you. It is a little bit of competition. The system pushes [the teachers] towards inner satisfaction when there is no material satisfaction [implying the money or awards teachers earn is not high]. Being a popular teacher, a teacher who is loved opens the gates for them and makes things easier. For example, when they will choose a book, none of the parents object. Even if the popular teacher scolds the students, even if they beat the students, the parents do not complain."

This view of P1 can show that all teachers do not embrace the school but some teachers only consider themselves responsible for their classes.

\section{Parents and students' culture}

School principals' views about 'attitudes of parents and students on distributed leadership" are presented under this theme.

P1's views on how parents perceive the school administrative were:

"That is to say there is this logic in our city that the school is equal to the school principal. Considering this, even if you distribute leadership and the work, eventually you would be the one responsible for things."

P10's views on parents' perceptions of school principals were:

“This relates to parents' education levels. Here [in this school: having uneducated parents profile], according to these parents, school principal knows and does everything."

P3's views on making parents leaders:

"For example, when you look at schools which there are more educated parents or parents who have certain positions, when you consider such schools, parents can become leaders. They might even surpass the school principal. I try to prevent parents surpassing the school principal. This is 
because people use their leadership spirits for themselves, for personal gains."

P4's views on making parents leaders:

"I do not make parents a leader in my opinion. From the moment he feels that he is a leader, I see that the parent will be the pressure factor on the teacher and that he will start teaching the teacher. For example, I do not collect money from parents for donations to school, because there are rich parents, poor parents. This time, the parents who have money and donate can make unfair demands at the school."

P1's view on appreciating the decisions that parents who make donations to the school:

"It affects psychologically. For example, think that a parent makes a donation [...] allowing them to speak, those parents are treated more respectfully."

P4's views on how students perceive school principals and its effect on distributed leadership:

"That student comes to you, the school principal and asks: 'I told my teacher but s/he did not do it, you can do it, you are the school principal'. When we get rid of this logic, I think what you [the interviewer] say [implying distributed leadership] could happen."

\section{National culture}

School principals' views on 'national culture' attitudes on distributed leadership" are presented under this theme.

P4's views suggesting that the national culture affects distributed leadership:

"Because of our culture, we need leaders. Our logic is always like that; when you compare it with the West, in our culture, there is this logic: 'I have 
rights but no responsibilities'. We cannot fully apply distributed leadership."

P7's views on national culture:

"Too jealous, too much. Especially this Central Anatolia region, unfortunately, there is no integration. So, let's unite, be strength together, solidarity, make it stronger; there is no such understanding." P15's views on national culture: "I do not particularly consider the Turkish society reliable."

According to these views, the national culture can show that distributing leadership in schools may carry some risks; because we share leadership with people we trust more.

\section{The centralized and bureaucratic structure}

School principals' views on the effects of "centralized and bureaucratic structure" on distributed leadership are presented under this theme. Turkey's Ministry of National Education has a centralized structure. As a result of this centralization, the authority to make final decisions is given to the headquarters. The bureaucratic structure is a tool for hierarchy; it allows the decisions from the headquarters made to reach school principals.

P10's views on the authority and power school principals have:

"The only think I would say is that the school principals do not have as much authority as they have responsibilities."

P13's views on the authority and power he has:

"If I had more power as the school principal, the first thing I would do would be to select my own staff." 
P11's views especially on how bureaucracy negatively affects leadership distribution:

"The bureaucracy prevents the distribution of leadership, but the attitudes of the people in the bureaucracy are very important. However, if the people with authority have leadership qualities, if they are worthy of their positions, the distribution of leadership may be possible. But this is very difficult for Turkey. Top management should accept, appreciate, and not be jealous of the success of the lower management (P11)."

P12 who is a school principal in a rural area explained that he did not take responsibility because of bureaucracy. These thoughts of P12 may show that they could not lead because of bureaucratic rules. Moreover, the number of people who share leadership in village schools is low. He adds that he works better with men.

"I continuously have worked in rural areas, in the schools that I worked there were a maximum of three teachers. School principals in rural areas do not do this job voluntarily. There would have been the possibility that a male colleague would help more. Social activities frighten us; we do not want to shoulder that responsibility; because, there are too many bureaucratic procedures. After all, the whole responsibility for this procedures is on me (P12).”

\section{Discussion and Conclusion}

The results of the present study suggested that legislation, school culture, parents' and students' culture, the national culture, and the centralized and bureaucratic structure affect that leadership in primary schools is shared among the school principal, teachers, and parents. Those factors were identified as the themes of this study.

It can be understood from the legislation regarding schools that the school principal is the first and most liable individual within a school. In addition, almost all of the school principals participating in this study 
believe that they should be only a leader in school and that they should be school principals and believed that all staff, except the principal, should be the co-leader within the school. School principals had the opinion that school staff, rather than being leaders, should be assistant leaders whose opinions need to be valued and who would take on responsibilities in schools. Otherwise, school principals believed that there would be too many leaders and too many voices in the school. Furthermore, competition among teachers and jealousy were among the reasons that made principles sceptic about distributing leadership to teachers. These results are in line with Barth et al.'s (1999) study. Moreover, school principals' justifications for the idea that the school principal should the prime leader were; school members' (e.g. teachers and parents) unfair requests that were against the rules and regulations, scarcity of teachers who want to take responsibilities at school, and human beings' need for coordination, control, and monitor.

According to participants, the number of teachers who had leadership qualities and took on responsibilities was relatively low. Majority of teachers would act as the school principal asks them to. Another minority group, on the other hand, consisted of teachers who did not want to take on responsibilities. Those were generally identified as teachers who are close to getting retired. School principal's views that teachers need to be monitored in general and that they are not eager to take on responsibilities brings the issue of teacher quality into consideration.

Teachers were keener on being leaders of individual classes. This is similar to Harris (2004) and Mintzberg (1979) who found that teachers have an autonomous position in schools. As exemplified in the results section, there was a school principal who stated that few teachers did not embrace the school but rather tried to bring their own class into the forefront and tried to increase their popularity. The reason for that was explained as teachers' attempt to compensate their need for rewards by earning parents' approval. This autonomy, however, might prevent teachers from actively undertaking leadership roles.

Harris (2004) found that distributed leadership in schools could be affected by financial barriers. Similarly, in this study, it has been found the 
communication between school principals and parents, which are focused on monetary issues, did in fact affect the distribution of leadership. School principals are, in general, cautious about sharing leadership with parents. According to school principals, as parents gain power, they might start making requests that are unfair or try to oppress teachers in the school. Few principles do not consider accepting donations from parents appropriate since it might put them in a difficult situation when parents make requests. On the other hand, other school principals explained that they treated parents from whom they received donations differently. Therefore, the financial realities of the school might put the parents in a privileged position.

School principals believed that the national culture pushed them towards being prime leaders. Few participants held the belief that as part of the national culture, especially in Central Anatolia region or in small cities, jealousy was a dominant feeling in Turkey. Those school principals believed that this feeling damaged the sense of unity and solidarity. One of the participants believed that the Turkish people did not take as much responsibility as they seek their rights. One of the participants did not find Turkish people reliable. Based on the results of Sargut's (2001) evaluation of the Turkish society following Hofstede's (1980) framework: Turkish society is a low-synergy society. The feelings of unity and solidarity are not strong in Turkish culture. Few of the participants in this study considered that Turkish people were in search of a leader and that they needed an authority that monitors them or a school principal who would be able to solve problems even if problems are beyond their authority. Yet another participant believed that one can make others do a task by appealing to their emotions, not rules or regulations.

The national education system in Turkey is governed by a centralized structure (Hallinger, 2018). According to participants, this kind of structure affected how they distributed leadership in their schools. This is because, in centralized structures, school principals always keep their anxiety about passing their decisions through the opinion filter of their superior. The current structure decreases principals' power and authority by making them dependent on legislations and their supervisor's views. It also causes the principals to feel that they have to monitor the responsibilities they assign to 
teachers and parents, and check the appropriateness of their requests in relation to the legislation. However, they do not have the authority to choose teachers to work with at school. Therefore, actullay, school principals felt that they did not have as much power and authority as their responsibilities. According to principals this situation, inevitably, pushes them to becoming the only authority in school. This authority carry risks that came with being a school principal who had the highest liability in schools and complained about that. Furthermore, there were also views that the ego of supervisors who were in positions that they did not deserve might have made the distribution of leadership more difficult. In Harris's (2004) study, hierarchical structures, current status quo, and individuals' egos were found to prevent distribution of leadership.

A school principal, who worked in a school located in a rural area, highlighted that the fact that there were not sufficient staff in rural schools, the physical conditions of the school (e.g. heating) were not good, teachers were not satisfied with how much they earned, and bureaucratic barriers prevented them from leading. The same school principal explained that his ideas relating to distributing leadership were negatively affected because of those reasons. This finding is similar to Hallinger (2018) who found that problems in rural schools affected school principals' leadership behaviours and raised the bar for them to be able to exhibit leadership behaviours.

In conclusion, this study revealed that legislations, school culture, parents' and students' culture, national culture, and centralized and bureaucratic structure affect the attitude school principals distribute leadership. In general, school principals believed that there should only be one leader in schools that person needed to be the school principal. School principals considered parents and teachers as assistants who undertake assignments when given, state their opinions, and need to be monitored when necessary. Even though one of the school principals reported that he realized the importance of team leadership thanks to the present study, in general, school principals considered any increase in the number of leaders within a school as a threat. Moreover, pariticipants' general perceptions is that individuals are not inclined to take responsibility in the Turkish or school culture but leadership means taking responsibility; this situation 
requires rethinking the issue of training responsible teachers for educational institutions. Although there was one participant who explained that distributed leadership can be achieved by giving the positions in centralized bureaucratic structures to those who deserve them, almost whole of school principals wanted the power to be able to select those with whom they will work. In fact, one of the participants even considered that he did not have as much power and authority as his responsibilities. To conclude, school principals generally do not want to share leadership with teachers or parents. While the justification about teachers is based on their reluctance to take responsibility or the negative competition between them, the justification for parents is based on the potential of parents' leadership to be a threat towards social justice at school. In addition, the law puts more responsibility on school principals, pushing them to become the leader of the school. However, school principals do not have as much authority as responsibility at schools. Thus, the hierarchical structure that intensifies the power in the center will provide more effective control over the school.

\section{Appendix}

\section{Interview questions}

1. How does the perception of the school community and the environmental community about school principals affect your understanding of sharing leadership in school?

2. How do you look at the fact that there are other leaders in the school other than you?

3. How do teachers' legal rights affect your understanding of sharing leadership at school?

4. How does the culture of teachers affect your understanding of sharing leadership at school?

5. How do the educational policies of the last 10 years affect your understanding of sharing leadership at school?

6. How does the bureaucratic management approach affect your understanding of sharing leadership at school? 
7. How do physical and economic services affect your understanding of sharing leadership at school?

8. How do the legal rights of parents affect your understanding of sharing leadership at school?

9. How does the culture of parents affect your understanding of sharing leadership at school?

10. How does the culture of cooperation established by teachers and parents at school affect your understanding of sharing leadership at school?

11. How does the coordination process at school affect your understanding of sharing leadership at school?

\section{References}

Allen, K. E., Stelzner, S. P., \& Wielkiewicz, R. M. (1999). The ecology of leadership: Adapting to the challenges of a changing world. Journal of leadership studies, 5(2), 62-82.

Angelle, P. S. (2010). An organizational perspective of distributed leadership: A portrait of a middle school. Rmle online, 33(5), 1-16.

Barth, P., Haycock, K., Jackson, H., Mora, K., Ruiz, P., Robinson, S. \& Wilkins, A. (1999) Dispelling the myth: high poverty schools exceeding expectations. New York: ACSD.

Bellibas, M. S., \& Liu, Y. (2018). The effects of school principals' perceived instructional and distributed leadership practices on their perceptions of school climate. International journal of leadership in education, 21(2), 226-244.

Bossert, S. T., Dwyer, D. C., Rowan, B., \& Lee, G. V. (1982). The instructional management role of the school principal. Educational administration quarterly, 18(3), 34-64.

Braun, A., Ball, S. J., Maguire, M., \& Hoskins, K. (2011). Taking context seriously: Towards explaining policy enactments in the secondary school. Discourse: Studies in the cultural politics of education, 32(4), 585-596.

Canales, A., \& Maldonado, L. (2018). Teacher quality and student achievement in Chile: Linking teachers' contribution and observable 
characteristics. International journal of educational development, 60, 33-50.

Christensen, L.B., Johnson, B. \& Turner, L.A. (2011). Research methods, design, and analysis. Boston: Pearson.

Copland, M. A. (2003). Leadership of inquiry: Building and sustaining capacity for school improvement. Educational evaluation and policy analysis, 25(4), 375-395.

Darling-Hammond, L. (2000). Teacher quality and student achievement. Education policy analysis archives, 8(1).

Dimmock, C., \& Walker, A. (2005). Educational leadership: Culture and diversity. Sage.

Dinham, S. (2005). School principal leadership for outstanding educational outcomes. Journal of educational administration, 43(4), 338-356.

Firestone, W. A., \& Cecilia Martinez, M. (2007). Districts, teacher leaders, and distributed leadership: Changing instructional practice. Leadership and policy in schools, 6(1), 3-35.

Garet, M. S., Porter, A. C., Desimone, L., Birman, B. F., \& Yoon, K. S. (2001). What makes professional development effective? Results from a national sample of teachers. American educational research journal, 38(4), 915-945.

Goldhaber, D. \& Anthony, E. (2003). Teacher Quality and Student Achievement. Urban Diversity Series. Newyork, NY: Teachers College Press. (Eric Document Reproduction Service No. ED477271)

Gronn, P. (2002). Distributed leadership as a unit of analysis. The leadership quarterly, 13(4), 423-451.

Hallinger, P. (2018). Bringing context out of the shadows of leadership. Educational management administration \& leadership, 46(1), 5-24.

Hallinger, P., \& Lu, J. (2014). Modelling the effects of school principal leadership and school capacity on teacher professional learning in Hong Kong primary schools. School leadership \& management, 34(5), 481-501.

Hallinger, P. (2011). Leadership for learning: Lessons from 40 years of empirical research. Journal of educational administration, 49(2), 125-142. 
Hallinger, P., \& Heck, R. H. (2010a). Collaborative leadership and school improvement: Understanding the impact on school capacity and student learning. School leadership and management, 30(2), 95-110.

Hallinger, P., \& Heck, R. H. (2010b). Leadership for learning: Does collaborative leadership make a difference in school improvement?. Educational management administration \& leadership, 38(6), 654678.

Hallinger, P., \& Heck, R. H. (2009). Distributed leadership in schools: Does system policy make a difference?. In distributed leadership (pp. 101-117). Springer, Dordrecht.

Hallinger, P., \& Heck, R. H. (1998). Exploring the school principal's contribution to school effectiveness: 1980-1995. School effectiveness and school improvement, 9(2), 157-191.

Hallinger, P., \& Heck, R. H. (1996). Reassessing the school principal's role in school effectiveness: A review of empirical research, 1980-1995. Educational administration quarterly, 32(1), 5-44.

Harris, A., Leithwood, K., Day, C., Sammons, P., \& Hopkins, D. (2007). Distributed leadership and organizational change: Reviewing the evidence. Journal of educational change, 8(4), 337-347.

Harris, A. (2004). Distributed leadership and school improvement: leading or misleading?. Educational management administration \& leadership, 32(1), 11-24.

Hartley, D. (2010). Paradigms: How far does research in distributed leadership 'stretch'?. Educational management administration \& leadership, 38(3), 271-285.

Heck, R. H., \& Hallinger, P. (2010a). Collaborative leadership effects on school improvement: Integrating unidirectional-and reciprocaleffects models. The elementary echool journal, 111(2), 226-252.

Heck, R. H., \& Hallinger, P. (2010b). Testing a longitudinal model of distributed leadership effects on school improvement. The leadership quarterly, 21(5), 867-885.

Heck, R. H., \& Hallinger, P. (2009). Assessing the contribution of distributed leadership to school improvement and growth in math achievement. American educational research journal, 46(3), 659689. 
Hofstede, G. (1980). Motivation, leadership, and organization: do American theories apply abroad?. Organizational dynamics, 9(1), 42-63.

Hoy, W. K., \& Tarter, C. J. (1992). Measuring the health of the school climate: A conceptual framework. NASSP bulletin, 76(547), 74-79.

Hulpia, H., Devos, G., Rosseel, Y., \& Vlerick, P. (2012). Dimensions of distributed leadership and the impact on teachers' organizational commitment: A study in secondary education. Journal of applied social psychology, 42(7), 1745-1784.

Hulpia, H., Devos, G., \& Van Keer, H. (2010). The influence of distributed leadership on teachers' organizational commitment: A multilevel approach. The journal of educational eesearch, 103(1), 40-52.

Humphreys, E. (2010). Distributed leadership and its impact on teaching and learning. (Phd. Dissertation). National University of Ireland, Maynooth, Ireland.

Leedy, P. D., \& Ormrod, J. E. (2001). Practical Research: Planning and Design, Merrill Prentice Hall. New Jersey.

Leithwood, K., Patten, S., \& Jantzi, D. (2010). Testing a conception of how school leadership influences student learning. Educational administration quarterly, 46(5), 671-706.

Leithwood, K. (2006). Teacher working conditions that matter: Evidence for change. Toronto, ON: Elementary Teachers' Federation of Ontario.

Lumpe, A., Czerniak, C., Haney, J., \& Beltyukova, S. (2012). Beliefs about teaching science: The relationship between elementary teachers' participation in professional development and student achievement. International journal of science education, 34(2), 153-166.

Mascall, B., Leithwood, K., Straus, T., \& Sacks, R. (2008). The relationship between distributed leadership and teachers' academic optimism. Journal of educational administration, 46(2), 214-228.

Merriam, S. B. (1988). Case study research in education: A qualitative approach. San Francisco: Jossey-Bass.

Miles, M. B., \& Huberman, A. M. (1994). Qualitative data analysis: An expanded sourcebook. sage.

Mintzberg, H. (1979). The Structuring of Organizations: A Synthesis of the Research. New Jersey: Prentice-Hall.

Park, V., \& Datnow, A. (2009). Co-constructing distributed leadership: District and school connections in data-driven decision-making. School leadership and management, 29(5), 477-494. 
Patton, M. Q. (2004). Qualitative research and evaluation methods 4th edition.

Pearce, C. L., Manz, C. C., \& Sims Jr, H. P. (2009). Where do we go from here?: Is shared leadership the key to team success?. Organizational dynamics, 38(3), 234-238.

Pearce, C. L. \& SimsJr, H. P. (2002). Vertical versus shared leadership as predictors of the effectiveness of change management teams: an examination of aversive, directive, transactional, transformational, and empowering leader behaviors. Group dynamics: Theory, research, and practice, 6(2), 172-197. SLEP

Rivkin, S. G., Hanushek, E. A., \& Kain, J. F. (2005). Teachers, schools and academic achievement. Econometrica, 73(2), 417-458.

Robinson, V. M., Hohepa, M., \& Lloyd, C. (2007). School leadership and student outcomes: Identifying what works and why (Vol. 41). Winmalee: Australian Council for Educational Leaders.

Sargut, S. (2001). Kültürler arası farklılaşma ve yönetim. Ankara: Verso Yayincilik.

Spillane, J. P. (2005). Distributed leadership. In the educational forum, 69(2), 143-150.

Spillane, J. P., Halverson, R., \& Diamond, J. B. (2001). Investigating school leadership practice: A distributed perspective. Educational researcher, 30(3), 23-28.

Stronge, J. H., Ward, T. J., Tucker, P. D., \& Hindman, J. L. (2007). What is the relationship between teacher quality and student achievement? An exploratory study. Journal of personnel evaluation in education, 20(3-4), 165-184.

Tan, C. Y. (2018). Examining school leadership effects on student achievement: the role of contextual challenges and constraints. Cambridge journal of education, 48(1), 21-45.

Thompson, J. D. (1967). Organizations in action: Social science bases of administrative theory. Transaction publishers. New York: McGrawHill.

Tschannen-Moran, M., Hoy, A. W., \& Hoy, W. K. (1998). Teacher efficacy: It's meaning and measure. Review of educational research, 68(2), 202-248. 
Witziers, B., Bosker, R. J., \& Krüger, M. L. (2003). Educational leadership and student achievement: The elusive search for an association. Educational administration quarterly, 39(3), 398-425.

Yıldırım, A., \& Şimşek, H. (2006). Sosyal bilimlerde nitel arastirma yöntemleri. Ankara: Seçkin yayıncılık.

Yoon, K. S., Duncan, T., Lee, S. W. Y., Scarloss, B., \& Shapley, K. L. (2007). Reviewing the Evidence on How Teacher Professional Development Affects Student Achievement. Issues \& Answers. REL 2007-No. 033. Regional Educational Laboratory Southwest (NJ1).

Yukl, G. (1999). An evaluation of conceptual weaknesses in transformational and charismatic leadership theories. The leadership quarterly, 10(2), 285-305.

Neşe Börü is an assistant professor in Nevşehir Hacı Bektaş Veli University. She received her $\mathrm{PhD}$ in education administration from University of Anadolu, Eskişehir. Her interests are in the areas of educational leadership, social justice and low socio-economic schools.

Contact Address: Department of Educational Sciences

College of Education

Hacı Bektaş Veli University, Nevşehir, TURKEY

E-mail: neshe.boru@gmail.com; nboru@nevsehir.edu.tr 